\title{
PENGEMBANGAN MODUL BERBASIS KONSTRUKTIVISME PADA MATA KULIAH ANALISIS VEKTOR DI UNRIKA
}

\author{
Asmaul Husna*, Nailul Himmi** \\ Program Studi Pendidikan Matematika, Fakultas Keguruan dan Ilmu Pendidikan, \\ Universitas Riau Kepulauan, Batam, Kepulauan Riau \\ e-mail:*asmaul_uul25@yahoo.com,**nailul.hsb@gmail.com
}

\begin{abstract}
Abstrak. Tujuan umum penelitian untuk mengembangkan modul analisis vektor yang valid di Program Studi Pendidikan Matematika UNRIKA. Tujuan khusus penelitian adalah menyediakan produk berupa modul Analisis Vektor berbasis Konstruktivisme. Untuk mencapai tujuan tersebut, diperlukan suatu rancangan penelitian. Rancangan penelitian ini diuraikan dalam prosedur penelitian, Prosedur penelitian yang digunakan model ADDIE yang terdiri dari 5 tahap, yaitu tahap analisis, tahap perancangan, tahap pengembangan, tahap implementasi dan tahap evaluasi. Instrumen yang digunakan berupa lembar penilaian modul dalam bentuk checklist yang diberikan kepada ahli materi dan ahli media untuk mengukur kevalidan. Data hasil validasi dari validator terhadap seluruh aspek yang dinilai, dianalisis secara kuantitatif dengan memberikan skor sesuai dengan skala yang ditetapkan yaitu pada rentang 1-4 dengan kategori sangat kurang-sangat baik. Hasil skor disajikan dalam bentuk tabel kemudian dicari persentase skor tersebut. Adapun hasil validitas modul dari ahli media diperoleh sebesar 78,92\% dengan kategori baik dan validitas modul dari ahli materi sebesar 78,57\% dengan kategori baik.
\end{abstract}

Kata Kunci: Analisis Vektor, Konstruktivisme, Modul

Abstract. General Purpose of the study to develop a valid Vektor Analysis module in the UNRIKA Mathematics Education Study Program. The specific purpose of the research is to provide products in the form of Constructivism-based Vektor Analysis modules. To achieve this goal, a research design is needed. The design of this study is described in the research procedure, the research procedure used by ADDIE model consists of 5 stages, namely the analysis stage, the design phase, the development stage, the implementation stage and the evaluation stage. The instrument used was a module assessment sheet in the form of a checklist given to material experts and media experts to measure validity. The validation data from the validator on all aspects that are assessed, are analyzed quantitatively by giving a score according to the specified scale in the range 1-4 with very less-very good category. The score results are presented in the form of tables and then look for the percentage of the score. The results of module validity from media experts were $78,92 \%$ with good categories and module validity from material experts was $78,57 \%$ with good categories..

Keywords: Vektor Analysis, Constructivism, Module

\section{Pendahuluan}

Mata kuliah Analisis vektor merupakan salah satu mata kuliah keahlian kependidikan yang wajib diikuti oleh seluruh mahasiswa program studi pendidikan matematika, guna mempersiapkan mereka dalam mengajarkan tentang konsep vektor disekolah tingkat SMP/MTs dan SMA/MA/SMK sederajat. Selain itu materi kuliah Analisis Vektor yang meliputi vektor konstan, fungsi vektor, differensial vektor dan integral vektor mempunyai peranan yang sangat penting bagi para matematikawan, fisikawan dan rekayasawan untuk membantu menyelesaikan permasalahannya. Oleh sebab itu mahasiswa pendidikan matematika perlu mendapat pengetahuan tentang materi ini.

Berdasarkan pengamatan yang dilakukan peneliti terhadap mahasiswa program studi pendidikan matematika Universitas Riau Kepulauan khususnya dalam perkuliahan Analisis 
Vektor, diperoleh keterangan bahwa dalam perkuliahan selama ini mahasiswa mengalami kesulitan untuk memahami materi yang ada. Dasar-dasar vektor telah diajarkan di SMA, terutama bagi siswa program IPA. Vektor disajikan dalam dua mata pelajaran yaitu Fisika dan Matematika, dua mata pelajaran yang menjadi momok bagi peserta didik (Akbar, 2013), (Handhika \& Kurniadi, 2016). Sementara belum ada satupun bahan ajar yang praktis dari dosen sebagai pegangan mahasiswa dalam perkuliahan tersebut. Bahan ajar yang dipakai hanya dari buku yang ada di perpustakaan saja, itupun jumlahnya terbatas, hal ini berefek pada rendahnya hasil belajar mahasiswa. Berdasarkan daftar nilai akademik mahasiswa program studi pendidikan matematika pada mata kuliah Analisis Vektor sebesar 80\% mahasiswa masih banyak mahasiswa yang memperoleh nilai dibawah 68 dari standar minimal nilai lulus pada matakuliah Analisis Vektor ini.

Dari hasil wawancara formal peneliti dengan beberapa mahasiswa dapat disimpulkan bahwa mahasiswa masih sebatas memahami materi konsep dasar dan belum bisa menghubungkan konsep antar materi, apalagi mata kuliah Analisis Vektor memiliki materi prasyarat yaitu mata kuliah Kalkulus 1, Kalkulus 2 dan Kalkulus lanjut. Akan tetapi fakta dilapangan menunjukkan banyak mahasiswa yang kurang menguasai atau sudah lupa dengan materi Kalkulus, sehingga ketika proses perkuliahan Analisis Vektor berlangsung disaat dosen mengajukan pertanyaan-pertanyaan kritis yang tidak seperti contoh soal, Mahasiswa mengalami kesulitan. Perilaku yang seperti ini menunjukkan bahwa Mahasiswa belum menguasai materi dengan baik dan hanya terbiasa menjawab soal seperti yang sudah dicontohkan dan kesulitan menghubungkan dengan materi prasyarat.

Mata kuliah Analisis Vektor mempunyai bobot 3 sks. Hal ini menuntut Mahasiswa untuk belajar mandiri di luar jam perkuliahan dengan tanpa bimbingan dari dosen. Ditambah lagi dengan kemampuan yang dimiliki Mahasiswa sangat bervariasi, sehingga dibutuhkan bahan ajar yang mampu mengarahkan Mahasiswa untuk belajar secara mandiri. Oleh karena itu perlu dikembangkan sumber belajar yang dapat digunakan untuk belajar mandiri sebagai bahan belajar selain buku acuan yang ada.

Salah satu strategi untuk meningkatkan pemahaman terhadap materi mahasiswa adalah dengan memberikan masalah sebagai stimulus. Sehingga diperlukan pengembangan sumber belajar salah satunya berbentuk modul matematika. Modul didesain dengan memberikan permasalahan-permasalahan yang lebih bersifat mengarahkan pada penemuan suatu konsep yang lahir dari pandangan, dan gambaran serta inisiatif mahasiswa (Boud, Felleti dan Fogarty dalam (Widiastuti, 2017). Penggunaan modul mampu meningkatkan pengetahuan mahasiswa untuk membangun sekaligus menemukan hal-hal baru, membuat pembelajaran yang lebih terpusat kepada mahasiswa (student centered) dalam proses pembelajaran serta lebih mengesankan untuk diingat dalam mencapai tujuan pembelajaran (Karmila \& Husna, 2013),(Widiastuti, 2017),(Lusiana, 2013). Ide ini sesuai dengan konsep pembelajaran Konstruktivisme. Nussbaum (Nurohman, 2008) memandang konstruktivisme sebagai sebuah konsep mayor yang ingin merubah paradigma "logical positivist" atau "objectivist", yaitu suatu logika yang memandang pengetahuan sebagai sesuatu yang absolut, menjadi 'relativistic view", bahwa pengetahuan disusun secara individu. Metode ini lebih menekankan pada keterlibatan Mahasiswa pada suatu masalah dengan maksud agar Mahasiswa dapat menyusun pengetahuan mereka sendiri dari hasil pemikiran terhadap penyelesaian masalah yang sudah ditemukan (Suherman, 2008). 
Penelitian seperti ini sudah pernah dilakukan sebelumnya di Universitas Riau Kepulauan, yaitu penelitian yang dilakukan oleh (Gusmania, 2010) dengan judul "Pengembangan Modul Geometri Analitik Bidang Berbasis Contextual Teaching and Learning (CTL) Untuk Meningkatkan Kompetensi Mahasiswa Universitas Riau Kepulauan" yang didanai oleh hibah dikti penelitian dosen pemula tahun anggaran 2015. Dari hasil penelitian tersebut diperoleh bahwa lebih dari $70 \%$ mahasiswa mendapatkan nilai lebih dari 68, ini berarti modul dapat dikatakan efektif. Berdasarkan hasil penelitin tersebut, peneliti tertarik untuk melakukan pengembangan modul pada mata kuliah berbeda dengan menggunakan motode yang berbeda. Oleh karena itu, peneliti melakukan penelitian yang berjudul "Pengembangan modul berbasis konstruktivisme pada mata kuliah Analisis Vektor". Harapannya dengan modul ini mahasiswa mempunyai sarana yang lebih mudah untuk belajar mandiri sehingga memiliki penguasaan materi dengan baik.

\section{Metode Penelitian}

Jenis penelitian ini adalah penelitian R\&D (Research and Development). Menurut (Sugiyono, 2016) penelitian dan pengembangan berfungsi untuk mengembangkan produk. Mengembangkan produk dalam arti yang luas dapat berupa memperbarui produk yang telah ada. Desain penelitian yang digunakan dalam penelitian ini adalah model pengembangan ADDIE yang terdiri dari lima tahap, yaitu Analysis, Design, Development, Implementation, dan Evaluation. Model pengembangan ini secara sistematis pada gambar 1:

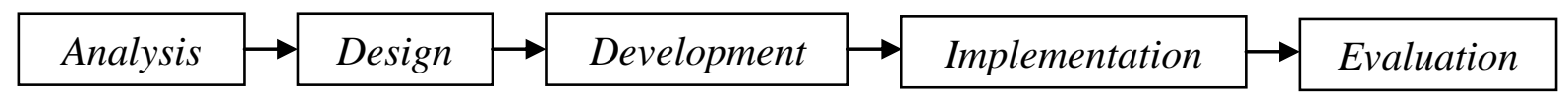

Gambar 1. Tahapan ADDIE

Tempat penelitian dilaksanakan di Prodi Pendidikan Matematika UNRIKA dengan subjek penelitian mahasiswa semester IV Tahun Akademik 2017/2018. Subjek penelitian sebanyak 42 mahasiswa. Instrumen penelitian yaitu menggunakan lembar validasi modul untuk mengukur kevalidan modul. Hasil validasi dari validator terhadap seluruh aspek yang dinilai, disajikan dalam bentuk Tabel. Selanjutnya dicari persentase skor tersebut dengan menggunakan rumus (Riduwan, 2005).

$$
P=\frac{\text { Jumlahskor padabutirtersebut }}{\text { Jumlahskor maksimal }} \times 100 \%
$$

Dengan, P : Persentase

Skor rata-rata yang diperoleh kemudian dikonversikan menjadi data kualitatif, dengan skor maksimal ideal (4) dan skor minimal ideal (1), yang disajikan pada tabel 1. 
Tabel 1. Konversi data kualitatif menjadi kriteria validitas

\begin{tabular}{cccc}
\hline Rentang Skor konversi kualitatif & Rentang Skor Validitas & Nilai & Kriteria \\
\hline$\overline{\boldsymbol{x}}>\boldsymbol{M}_{\boldsymbol{i}}+\mathbf{1}, \mathbf{8} \boldsymbol{S} \boldsymbol{B}_{\boldsymbol{i}}$ & $\bar{x}>3,4$ & $\mathrm{~A}$ & sangat valid \\
$\boldsymbol{M}_{\boldsymbol{i}}+\mathbf{0}, \mathbf{6}<\boldsymbol{S} \boldsymbol{B}_{\boldsymbol{i}} * \overline{\boldsymbol{x}} \leq \boldsymbol{M}_{\boldsymbol{i}}+\mathbf{1}, \mathbf{8} \boldsymbol{S} \boldsymbol{B}_{\boldsymbol{i}}$ & $2,8<\bar{x} \leq 3,4$ & $\mathrm{~B}$ & Valid \\
$\boldsymbol{M}_{\boldsymbol{i}}-\mathbf{0}, \mathbf{6}<\boldsymbol{S} \boldsymbol{B}_{\boldsymbol{i}} * \overline{\boldsymbol{x}} \leq \boldsymbol{M}_{\boldsymbol{i}}+\mathbf{0}, \mathbf{6} \boldsymbol{S} \boldsymbol{B}_{\boldsymbol{i}}$ & $2,2<\bar{x} \leq 2,8$ & $\mathrm{C}$ & cukup valid \\
$\boldsymbol{M}_{\boldsymbol{i}}-\mathbf{1}, \mathbf{8}<\boldsymbol{S} \boldsymbol{B}_{\boldsymbol{i}} * \overline{\boldsymbol{x}} \leq \boldsymbol{M}_{\boldsymbol{i}}-\mathbf{0 , 6} \boldsymbol{S} \boldsymbol{B}_{\boldsymbol{i}}$ & $1,6<\bar{x} \leq 2,2$ & $\mathrm{D}$ & kurang valid \\
$\overline{\boldsymbol{x}} \leq \boldsymbol{M}_{\boldsymbol{i}}-\mathbf{1 , 8} \boldsymbol{S} \boldsymbol{B}_{\boldsymbol{i}}$ & $\bar{x} \leq 1,6$ & $\mathrm{E}$ & tidak valid \\
\hline & & & (Widiyoko, 2007)
\end{tabular}

Keterangan :

$\bar{x}$

Skor maksimal ideal

Skor minimal ideal

Mi (mean ideal)

SBi (simpangan baku ideal)
= Nilai Rata-rata

$=$ jumlah indikator $\mathrm{x}$ skor tertinggi

$=$ jumlah indikator $\mathrm{x}$ skor terendah

$=\frac{1}{2}($ skor maks ideal + skor min ideal $)$

$=\frac{1}{6}($ skor maks - skor min $)$

Berikut perhitungan kriteria kategori kevalidan modul :

1. Ahli Materi

Jumlah item pernyataan $=33$ item

Skor maks ideal

$=4 \times 33=132$

Skor min ideal

$=1 \times 33=33$

$\mathrm{Mi}$

$=\frac{1}{2}(132+33)=82,5$

Sbi

$$
=\frac{1}{6}(132-33)=16,5
$$

Tabel 2. Kriteria Kevalidan Modul Ahli Materi

\begin{tabular}{cc}
\hline Rentang Skor & Predikat \\
\hline $\mathbf{1 1 2 , 2}<\overline{\boldsymbol{X}}$ & Sangat Baik \\
$\mathbf{9 2 , 4}<\overline{\boldsymbol{X}} \leq \mathbf{1 1 2 , 2}$ & Baik \\
$\mathbf{7 2 , 6}<\overline{\boldsymbol{X}} \leq \mathbf{9 2 , 4}$ & Cukup Baik \\
$\mathbf{5 2 , 8}<\overline{\boldsymbol{X}} \leq \mathbf{7 2 , 6}$ & Kurang \\
$\overline{\boldsymbol{X}} \leq \mathbf{5 2 , 8}$ & Sangat Kurang \\
\hline
\end{tabular}

2. Ahli Media

Jumlah item pernyataan $=27$ item

Skor maks ideal $\quad=4 \times 27=108$

Skor min ideal $\quad=1 \times 27=27$

$\mathrm{Mi}$

$=\frac{1}{2}(108+27)=67,5$

Sbi

$$
=\frac{1}{6}(108-27)=13,5
$$


Tabel 3. Kriteria Kevalidan Modul Ahli Media

\begin{tabular}{cc}
\hline Rentang Skor & Predikat \\
\hline $\mathbf{9 1 , 8}<\overline{\boldsymbol{X}}$ & Sangat Baik \\
$\mathbf{7 5 , 6}<\overline{\boldsymbol{X}} \leq \mathbf{9 1 , 8}$ & Baik \\
$\mathbf{5 9 , 4}<\overline{\boldsymbol{X}} \leq \mathbf{7 5 , 6}$ & Cukup Baik \\
$\mathbf{4 3 , 2}<\overline{\boldsymbol{X}} \leq \mathbf{5 9 , 4}$ & Kurang \\
$\overline{\boldsymbol{X}} \leq \mathbf{4 3 , 2}$ & Sangat Kurang
\end{tabular}

Dalam penelitian ini modul dikatakan valid apabila hasil rata-rata penilaian validator minimal berada pada kategori baik.

\section{Hasil Penelitian dan Pembahasan}

\section{Hasil Penelitian}

Berdasarkan model pengembangan ADDIE, langkah-langkah pengembangan modul analisis vektor berbasis konstruktivisme dilakukan melalui tahapan berikut:

\section{Tahap Analisis}

Tahap analysis (analisis) dalam penelitian ini meliputi analisis kurikulum, analisis karakter mahasiswa dan analisis referensi, yang dipaparkan sebagai berikut:

a. Analisis kurikulum

Kurikulum yang digunakan di UNRIKA adalah KKNI. Analisis kurikulum berguna untuk menetapkan kompetensi yang akan dikembangkan melalui bahan ajar. Pada tahap ini, peneliti menganalisis Rencana Pembelajaran Semester (RPS) matakuliah Analis Vektor yang digunakan di Universitas Riau Kepulauan. Dalam RPS terdapat 6 pokok bahasan yang akan dipelajari, antara lain: 1) Vektor dan Skalar, 2) Hasil Kali Titik dan Silang, 3) Diferensiasi Vektor, 4) Gradien, Divergensi dan Curl, 5) Integrasi Vektor, dan 6) Teorema Divergensi, Teorema Stokes dan Teorema - Teorema Integral yang Berkaitan. Karena keterbatasan waktu penelitian, maka materi yang dikembangkan pada vektor, skalar dan Integrasi vektor.

b. Analisis karakter

kemampuan akademik individu berbeda khususnya mahasiswa Semester IV Tahun Ajaran 2017/2018 berasal dari latar belakang sekolah menengah yang berbeda-beda, ada yang berasal dari SMA program IPA, IPS dan Sekolah Menengah Kejuruan (SMK) dalam berbagai macam jurusan. Hal ini mempengaruhi cara belajar, motivasi mahasiswa dalam perkuliah serta kemampuan awal dari setiap mahasiswa. Dari segi kemampuan ekonomi, rata-rata kemampuan ekonomi mahasiswa berada pada golongan menengah ke bawah, dan hanya sebagaian kecil mahasiswa bergolongan atas. Sehingga, sebahagian besar mahasiswa bekerja untuk memenuhi kebutuhan hidup dan membayar uang kuliah, serta kurang mampu dalam membeli buku referensi.

c. Analisis reverensi

Buku - buku referensi yang digunakan belum mampu menjadi sumber belajar yang memfasilitasi mahasiswa dengan latar belakang sekolah menengah yang berbeda-beda dikarenakan buku referensi yang ada adalah buku terbitan lama dan berbahasa asing. 


\section{Tahap Perancangan}

Adapun tahap perancangan berupa:

a. Mencari buku-buku referensi dan gambar-gambar pendukung (Himmi \& Hatwin, 2018) yang berkaitan dengan analisis vektor

b. Membuat garis besar isi modul yaitu vektor, scalar dan integrasi vektor

c. Menyusun instrumen penelitian modul dari BNSP yang sudah dimodifikasi berupa angket yang terdiri dari 24 butir pernyataan untuk ahli materi dan 27 butir pernyataan untuk ahli media.

d. Menyusun instrument esai tes untuk hasil belajar analisis vektor

e. Menyusun angket respon siswa untuk mengukur tingkat kepraktisan modul.

\section{Tahap Pengembangan}

Setelah dilakukan perecanaan produk, langkah selanjutnya ada pengembangan produk, antara lain:

a. Mengembangkan Modul Berbasis Konstruktivisme

Modul yang dikembangkan terdiri dari tiga bagian, yaitu bagian awal, bagian isi dan bagian akhir.

1. Bagian Awal terdiri dari: Cover modul, Penulis Modul, Gambar Pendukung seperti gambar 2 yang berkaitan dengan analisis vektor seperti gambar 3, Kata Pengantar, Daftar isi.

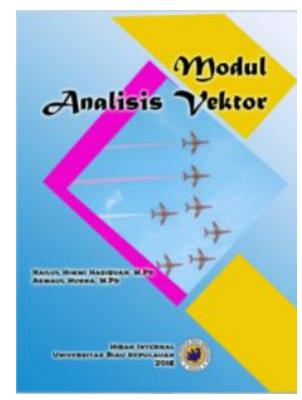

\section{Gambar 2. Cover Modul Analis Vektor}

2. Bagian isi seperti gambar 3 yang terdiri dari: Materi pokok dan tujuan pembelajaran, uraian Materi yang disusun berbasis konstruktivisme yang sesuai dengan pencapaian kompetensi, contoh soal yang berisikan soal-soal beserta penyelesaian sesuai kompetensi yang akan dicapai, latihan terbimbing yang berisikan latihan untuk membimbing mahasiswa sebagai membimbing untuk tercapainya kompetensi, latihan mandiri yang berikan sebagai tugas yang dilakukan secara mandiri. 

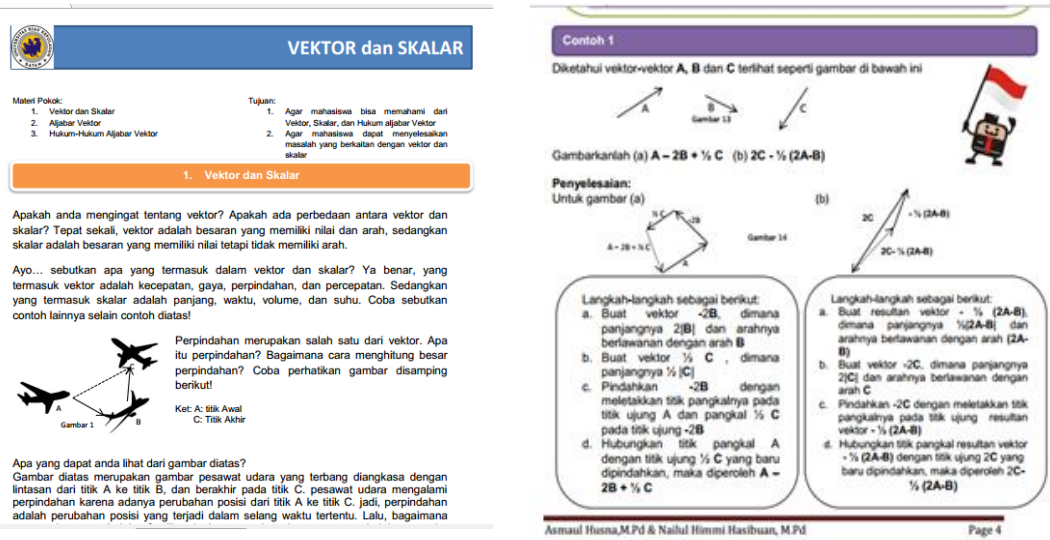

Gambar 3. Bagian Inti Modul Analisis vektor

3. Bagian akhir terdiri atas: Glosarium, dan Daftar pustaka.

\section{b. Tahap validasi}

Outline Modul Analisis Vektor yang telah selesai disusun, selanjutnya divalidasi oleh pakar/ahli sejawat di bidang pendidikan matematika yaitu Nina Agustyaningrum, M.Pd sebagai ahli materi dan Riska Novia Sari, M.Pd sebagai ahli media. Adapun hasil kelayakan Isi modul seperti yang disajikan pada tabel 4

Tabel 4. Rata-rata Hasil Validasi Kelayakan Isi Modul

\begin{tabular}{clc}
\hline No & \multicolumn{1}{c}{ Aspek yang dinilai } & Nilai Validator \\
\hline 1. & KELAYAKAN ISI & 6,5 \\
2. & KELAYAKAN PENYAJIAN & 12,5 \\
3. & KELAYAKAN BAHASA & 16,4 \\
4. & PENILAIAN KONSTRUKTIVISME & 2,8 \\
\hline \multicolumn{2}{c}{ TOTAL }
\end{tabular}

Adapun persentase kecapaian dari ahli materi sebagai berikut:

$$
P=\frac{f}{n} \times 100 \%=\frac{44.2}{56} \times 100 \%=78,92 \%
$$

Berdasarkan perolehan persentase pencapa aspek materi sebesar 78,92\% dan termasuk pada kategori baik. Komentar dan saran validator dijadikan sebagai bahan pertimbangan untuk penyempurna modul. Selanjutnya pada tabel 5 berikut sebagai hasil kelayakan Penyajian Modul

Tabel 5. Rata-rata Hasil Validasi Kelayakan Penyajian Modul

\begin{tabular}{lll}
\hline No & Aspek yang dinilai & Nilai validator \\
\hline 1. & Kelayakan ukuran & 7 \\
2. & Desain sampul modul & 15,5 \\
3. & Desain isi modul & 21,5 \\
\hline \multicolumn{2}{l}{ Total } & 44 \\
\hline
\end{tabular}


Adapun persentase kecapaian dari ahli media sebagai berikut:

$$
P=\frac{f}{n} \times 100 \%=\frac{44}{56} \times 100 \%=78,57 \%
$$

Berdasarkan perolehan persentase pencapa aspek materi sebesar 78,57\% dan termasuk pada kategori baik. Komentar dan saran validator dijadikan sebaagai bahan pertimbangan untuk penyempurna modul. Berdasarkan perolehan dari kedua aspek maka diperoleh rata-rata pencapaian kevalidan modul adalah 78,74\% dan termasuk kategori baik. Artinya modul valid dan layak untuk digunakan.

\section{Tahap Implementasi}

Setelah mendapatkan modul yang valid, selanjutnya akan dilakukan implementasikan. Implementasi di lakukan berupa uji coba pada mahasiswa pendidikan matematika Universitas Riau Kepulauan semester IV Tahun Akademik 2017/2018. Uji coba produk dilakukan pada bulan April 2018 selama 4x pertemuan sebanyak 3 sks. Selanjutnya mahasiswa diberikan angket untuk mengetahui kepraktisan modul. Hasil analisis praktikalitas dari ujicoba ini dijelaskan pada bagian analisis praktikalitas.

\section{Tahap Evaluasi}

Tahap evaluasi, dilakukan kegiatan untuk mengevaluasi apakah prototype versi uji coba dapat digunakan sesuai dengan harapan dan efektif dalam menunjang kualitas hasil belajar mahasiswa pada matakuliah Analisis Vektor. Aspek efektifitas dilihat dari penilaian tes hasil belajar mahasiswa setelah melakukan perkuliahan dengan menggunakan modul. Hasil dari penilaian keefektifan modul dijelaskan pada bagian analisis efektifitas modul. Selain itu melakukan revisi akhir dilakukan berdasarkan hasil pengamatan selama proses uji coba di kelas. Adapun beberapa kekurangan dalam modul sehingga perlu direvisi, diantaranya:

1. Menggantikan lambang " $x$ " menjadi " $\times$ "

2. Menambah space ruang pada latihan terbimbing.

\section{Pembahasan Penelitian}

Berdasarkan uraian yang telah diuraikan sebelumnya, langkah-langkah pengembangan modul Analisis Vektor berbasis Konstruktivisme pada mahasiswa semester IV Universitas Riau Kepulauan Tahun Akademik 2017/2018 menggunakatan lima tahap pengembangan ADDIE, menghasilkan dari ahli materi sebesar 78,92\% dan dari ahli media sebesar 78,57\% yang dikategorikan baik $(77,45 \%)$ yang memberikan arti bahwa modul layak untuk digunakan.

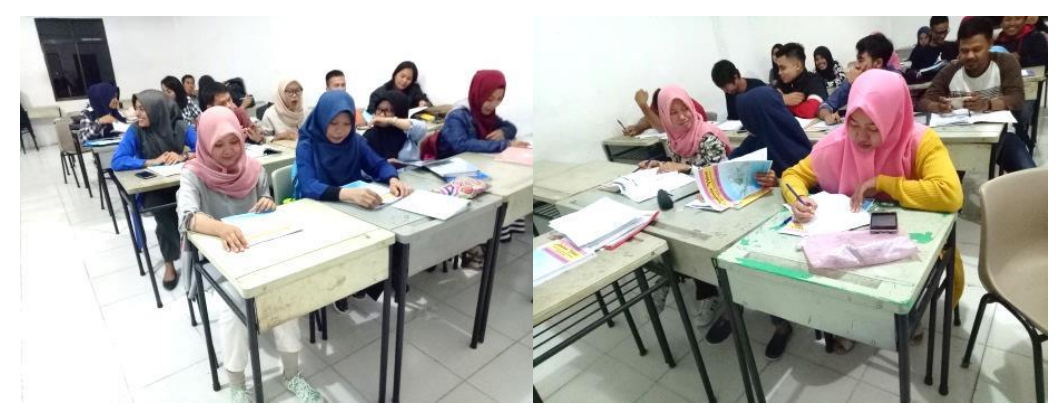

Gambar 5. Aktifitas belajar mahasiswa 
Modul yang valid sangat menunjang kemajuan dalam proses pembelajaran analisis vektor berbasis konstruktivisme, mahasiswa langsung membentuk kelompok kecil untuk belajar tanpa dikomando. Mahasiswa sangat antusias untuk mempelajari konsep-konsep yang diberikan pada modul analisis vektor serta menjawab latihan-latihan yang diberikan. Mahasiswa mendengarkan arahan yang diberikan dosen serta menanyakan kembali hal-hal yang tidak dimengertinya.

\section{Kesimpulan Dan Saran}

Berdasarkan hasil penelitian dan pembahasan terhadap modul analisis vektor berbasis konstruktivisme pada mahasiswa semester IV Universitas Riau Kepulauan Tahun Akademik 2017/2018 yang dikembangkan diperoleh nilai kevalidan dari ahli materi sebesar 78,92\% dan dari ahli media sebesar 78,57\% yang dikategorikan baik.

Saran yang peneliti sampaikan dari penelitian pengembangan ini adalah: (1) Modul Analis Vektor berbasis Konstruktivisme dapat dimanfaatkan dalam matakuliah analisis vektor. (2) Adanya pengembangan lebih lanjut terkait isi materi modul serta penyajiannya sehingga dapat menghasilkan produk pengembangan yang lebih baik lagi terkait materi dan pemanfaatannya. (3) Menggunakan model pembelajaran konstruktivisme saat penggunaan modul. (4) Dalam waktu implementasi lebih dari 4 kali pertemuan.

\section{Daftar Pustaka}

Akbar, I. (2013). Pengembangan Media Pembelajaran Ebook Berbasis-Web dengan Menggunakan LaTeX pada Matakuliah Analisis Vektor.

Gusmania, Y. dan T. P. (2010). Pengembangan Modul Geometri Analitik Bidang Berbasis Contextual Teaching Learning (CTL) untuk Meningkatkan Kompetensi Mahasiswa Universitas Riau Kepulauan (UNRIKA). Dimensi, 4(3), 1-11. Retrieved from http://journal.unrika.ac.id/index.php/jurnaldms/article/view/44/42

Handhika, J., \& Kurniadi, E. (2016). Peningkatan Hasil Belajar Mahasiswa Pokok Bahasan Analisis Vektor Melalui Inkuiri Terbimbing. Jurnal Pendidikan Fisika Dan Keilmuan (JPFK), 2(1), 12-15.

Himmi, N., \& Hatwin, L. B. A. (2018). Pengembangan modul sistem pertidaksamaan dua variabel berbasis geogebra terhadap kemampuan visual thinking matematis siswa kelas x. Pythagoras, 7(April), 35-46.

Karmila, E., \& Husna, A. (2013). Peningkatan Kreativitas Siswa Dalam Membuat Karya Kerajinan Tangan Melalui Pendekatan Kontruktivisme Di Kelas Iv Sekolah Dasar Negeri 25 Air Dingin Kecamatan. Dimensi, 4(2), 1-12.

Lusiana, R. (2013). Profil Pemahaman Mahasiswa Dalam Menyelesaikan Soal-Soal Trigonometri Pada Mata Kuliah Analisis Vektor Restu Lusiana, S.Pd., M.Pd. IKIP PGRI Madiun, Kota Madiun. JIPM, 2(1).

Nurohman, S. (2008). Peningkatan Thinking Skills Melalui Pembelajaran IPA Berbasis Konstruktivisme di Sekolah Alam. Jurnal Penelitian Dan Evaluasi Pendidikan, 9(1), 129-144. https://doi.org/10.21831/PEP.V11I1.1423 
Riduwan. (2005). Belajar Mudah Penelitian untuk Guru, Karyawan dan Peneliti Pemula. Bandung: Alphabeta.

Sugiyono. (2016). Metode Penelitian Pengembangan Research and Development. Bandung: Alphabeta.

Suherman, E. (2008). Belajar dan Pembelajaran Matematika. Bandung: Tidak Diterbitkan.

Widiastuti, T. T. (2017). Pembelajaran Dengan Bahan Ajar Berbasis Masalah Untuk Meningkatkan Kemampuan Pemecahan Masalah Pada Mata Kuliah Analisis Vektor Semester Iv Prodi Pendidikan Matematika Tahun Pelajaran 2015/2016. JES-MAT, 3(1), $11-19$.

Widiyoko. (2007). Evaluasi Program Pembelajaran. Yogyakarta: Pustaka. 